\title{
The Impact of Leadership in the Achievement of Goals and Objectives in Secondary Schools in Gweru District of Zimbabwe: Teachers' Perpectives Willard Nyathi $^{{ }^{*}}$, Caxton Shonhiwa ${ }^{2}$
}

${ }^{1}$ Dean Faculty of Education, Amadi University

${ }^{2}$ Senior Lecturer, Faculty of Commerce, Zimbabwe Open University

DOI: $10.36347 /$ sjahss.2020.v08i09.009

| Received: 03.09.2020 | Accepted: 10.09.2020 | Published: 25.09.2020

*Corresponding author: Willard Nyathi

Abstract

Original Research Article

This study sought to examine the impact of the school head's leadership in the achievement of goals and objectives using the quantitative methodology. The study adopted the descriptive survey design. The target population comprised of all secondary school teachers from Gweru District in the Midlands Province in Zimbabwe. The sample consisted of 240 teachers randomly sampled and of these, 128 were females and 112 males. All the information was collected through a questionnaire which largely had close-ended questions and two-open ended questions. The study revealed that the majority of teachers were not confident with the leadership provided by their heads. The study recommends that the Ministry of Primary and Secondary Education should prioritise training or retraining of heads on leadership skills.

Keywords: Leadership, secondary school, district, achievement, goals, impact.

Copyright @ 2020: This is an open-access article distributed under the terms of the Creative Commons Attribution license which permits unrestricted use, distribution, and reproduction in any medium for non-commercial use (NonCommercial, or CC-BY-NC) provided the original author and source are credited.

\section{INTRODUCTION}

In Zimbabwe, schools and education authorities have become accountable to the public for the education they provide. They are expected to provide good value for the considerable sums of money invested in the education system [1]. Heads of schools are therefore expected to inspire, encourage and impel those under them to work hard and with enthusiasm in order to achieve the institutional goals and objectives [2]. According to Madziyire [3] a head's leadership style impacts on the attainment of his/her school's goals. The most effective schools seem to be those that have created a positive atmosphere based on a sense of community and shared values [4]. Indeed, the head's work as a leader is to work with and through people to achieve goals of the school. The head should establish priorities and expected standards for the school and make everyone in the school know the expected standards of behavior and academic performance at the school [5].

As a school leader therefore, the head should use their skills to help individuals or teams of people to achieve the goals of the school. As Billing [6] argues, leadership from the head can effectively enhance the whole school system or misdirect it. The improvement of the teaching and learning process in the school is dependent upon the head's influence towards goal achievement [6]. Acheson and Gall [7] further point out that the responsibility of an influential head is to set standards and develop school policies which focus on educational goals and pupils' achievement. Ndlovu [8] echoes the same view when he states that heads are required to set goals and define the purpose of schooling to ensure learning takes place. Madziyire [3] asserts that influential leadership identifies and secures resources to support quality education in the school. Resources in the school exist in the form of finance, personnel, equipment and time [3]. It is on account of the information above that this study sought to examine the influence of the head's leadership in the achievement of goals and objectives in Zimbabwean secondary schools.

\section{LITERATURE REVIEW}

According to Knezevich [9] leadership is a process of stimulating, developing, and working with people within an organisation. It is a human-oriented process and focuses upon personnel motivation, human relationships or social interactions, interpersonal communications, organizational climate, interpersonal conflicts, personal growth and development and enhancement of the productivity of human factors in general [9]. Clearly, from this definition, leadership 
requires a good working relationship with people within an organisation. On the other hand, Cooper and Alvarado [10] refer to leadership as a process of applying influential forces by administrators and supervisors so as to bring about change to improve schooling and achieve designed goals and objectives.

Madziyire [3] argues that influential leadership identifies and secures resources to support quality education in the school. Dzvimbo [1] states that very often the leader has to be responsible for allocating or relocating resources including those that are scarce. Quite often the leader has to decide on which department can be allocated more funds in accordance with his / her priorities. Leadership, therefore, according to Moyo [11] is responsible for resource acquisition and disbursement. Resource allocation may generate conflict resulting in lack of cooperation from some teachers. Nadler [4] points out that it is important for a leader to maintain a high level of transparency and ensure that members of staff understand reasons behind the allocation of resources.

Another important function of the head of school as the leader involves supervision of curriculum implementation [12]. Curriculum is the vehicle through which people are educated in the classroom. As Hoy and Miskel [13] stated, one of the most important responsibilities of a school head is the collection of data in order to determine whether and to what extent educational objectives have been or are being achieved at his / her school. It is, therefore, the duty of every head to supervise teachers so that he/she becomes familiar with the work of each of the teachers and know their strengths and weaknesses in order to offer assistance for the improvement of the teaching / learning process. Mpofu [14] says the head can help teachers in ensuring high academic standards by setting vigorous demands, conducting orderly and well managed classrooms, ensuring students discipline, implementing instructional practices that promote students' achievement and providing opportunities for students' responsibility and leadership.

Leadership also plays a major role in staff development by providing teachers with the capacities and skills to improve instruction [12]. This can be done by providing the teachers with knowledge, competencies and fostering commitment of the staff to the objectives that their pupils are supposed to learn [12]. Ncube [15] adds and states that the head's responsibilities in staff developing teachers is to ensure that each member of staff becomes and remains a fully competent and responsive teacher of his / her subject, and he / she becomes capable of doing his / her job more effectively in his / her present role. Harris [16] echoes the same view when he postulates that it is crucial for the head to exert positive influence during staff development sessions. The head should orient new members of staff to policies, aims and objectives of the school. In this regard, the head has to exert positive influence on the staff.

Madziyire [3] states that the leader is also responsible for creating a climate that is supportive of teachers. Climate refers to the tone of an organisation. The effectiveness of an organisation depends, to a large extent, on its climate. A leader's decisions with regards to the structure of an organisation, leadership style and philosophy of leading, influence the climate of the school, which, in turn, influences the effectiveness of the organisation [17]. The other factors important to organizational climate are the types of motivation, communication and delegation within the organisation. Madziyire [3] further argues that climate provides a context within which a leader practices leadership. It is a necessary link between organizational structure and teacher attitude and behaviour. Thus, a leader who is autocratic creates a climate which is coercive and breeds friction, low morale and a feeling of powerlessness among staff members [18]. In a school, these feelings are transferred to pupils and negatively affect effectiveness. Climate determines what staff members do, how they relate to each other and the quality of pupil achievement and other gains an organisation can achieve. It also affects such outputs as satisfaction, activity and group decision-making [18].

\section{Statement of the Problem}

The quality of leadership in a school determines the quality of teaching and learning that takes place in various schools. This study examined the influence of heads as leaders in the achievement of goals and objectives in secondary schools through teachers' views.

\section{Purpose of the Study}

The study sought to highlight the various aspects in the heads' leadership styles that hindered the accomplishment of goals and objectives in order to minimize their negative effects on the learning of pupils in the schools by suggesting alternative courses of action.

\section{Research Questions}

1. What are the purposes of leadership?

2. What leadership styles are used by heads in schools?

3. How are the school climates affecting accomplishment of goals in schools?

4. Do heads of schools provide staff development programmes to enhance the performance of their teachers?

\section{Significance of the Study}

The significance of the study stemmed from the fact that it attempted to unveil the influence of leadership by heads in the achievement of goals and objectives in schools so as to assist the heads to provide effective leadership in the schools. The research hopes 
to bring awareness to the importance of the process of leadership to education authorities so that support structures are put in place or strengthened to promote effective leadership for accomplishment of school goals and objectives.

\section{Limitations of the Study}

The study employed a relatively small sample to make generalizations about the whole of Zimbabwe. It has to be pointed out also that attitudes about an issue are essentially subjective and cannot be measured accurately [19]. In other words, attitudes have no universally recognized and accepted scales of measurement and measures that were used in this study cannot be considered to be very accurate.

\section{Delimitations of the Study}

The study was concerned with the influence of school leadership in the achievement of goals and objectives in one district in the Midlands Province which is Gweru District. The study used a sample of 240 teachers randomly sampled. Perceptions from other stakeholders like heads of schools, education officers, school development committee members, parents and pupils were outside the purview of this study.

\section{RESEARCH METHODOLOGY}

The study used the quantitative methodology and made use of a survey research design. According to Leedy [20], the descriptive survey method looks with intense accuracy at the phenomenon of the moment and then describes precisely what the researcher sees. The questionnaire was used as the instrument for collecting data because as Anderson [21] argues, it increases reliability as an instrument of gathering data because of its greater impersonality.

\section{Data Collection and Analysis}

Data were gathered by means of a questionnaire which was made up of both close-ended and open-ended questions. The questionnaire was chosen because as Blumberg [19] posits, it has the ability to reach many respondents who live at widely dispersed addresses and preserves anonymity which encourages greater honesty. However, as Cresswell [22] postulates, the questionnaire has a low response rate and is inflexible in that it does not allow ideas or comments to be explored in-depth and many questions may remain unanswered. This was mitigated by pilot testing the questionnaire. The researchers personally distributed the questionnaires to the schools understudy. The same method was used to collect the completed questionnaires in order to maximize on the rate of return of the instrument. Non-returns as Borg and Gall [23] argue, introduce a bias in as much as they are likely to differ in many ways from respondents thereby adversely affecting reliability and validity. Data produced from the questionnaire produced descriptive statistics around the variables under study. These statistics were computed and inferential implications from them derived and recorded.

\section{FINDINGS AND DISCUSSION}

The study set out to examine the impact of the leadership of secondary school heads in the achievement of goals and objectives of their schools. This section is presented in two parts, namely, presentation of data and discussion.

\section{Presentation of Data}

Table-1: Distribution of Respondents by sex $(\mathbf{N}=\mathbf{2 4 0})$

\begin{tabular}{|l|l|l|}
\hline Sex & Frequency & Percentage \\
\hline Male & 112 & 47 \\
Female & 128 & 53 \\
\hline Totals & $\mathbf{2 4 0}$ & $\mathbf{1 0 0}$ \\
\hline
\end{tabular}

The information on table 1 above shows that the sample had more females $(53 \%)$ than male (47\%).
This statistic signifies the preponderance of women teachers in Zimbabwean secondary schools.

Table-2: Composition of Respondents by Age ( $\mathrm{N}=140)$

\begin{tabular}{|l|l|l|}
\hline Age in Years & Frequency & Percentage \\
\hline Below 20 & 0 & 0 \\
$20-29$ & 29 & 12 \\
$30-39$ & 134 & 56 \\
$40-49$ & 60 & 25 \\
50 and above & 17 & 7 \\
\hline Totals & $\mathbf{2 4 0}$ & $\mathbf{1 0 0}$ \\
\hline
\end{tabular}

Table 2 above shows that the majority of teachers in the sample were above 30 years of age and below 50 years $(88 \%)$. Those below 30 years constituted $12 \%$ of the sample and those above 50 comprised $7 \%$ of the respondents. The implications of this data are that the majority of teachers in the study are mature people who require experienced and skilled leaders to guide them. 
Table-3: Composition of respondents by working experience $(\mathrm{N}=\mathbf{2 4 0})$

\begin{tabular}{|l|l|l|}
\hline Experience in Years & Frequency & Percentage \\
\hline $0-5$ & 14 & 6 \\
$6-10$ & 58 & 24 \\
$11-15$ & 132 & 55 \\
$16-20$ & 24 & 10 \\
Over 20 & 12 & 5 \\
\hline Totals & $\mathbf{2 4 0}$ & $\mathbf{1 0 0}$ \\
\hline
\end{tabular}

The information on table 3 shows that the majority of the respondents fell within the 11-15 years of experience $(55 \%)$, followed by $6-10$ years of experience $(24 \%)$ and the 16-20 years of experience
(10\%) respectively. Those who fell within the $0-5$ years' age group were $(6 \%)$ and those over 20 years of work experience were $5 \%$ of the sample.

Table-4: Responses to the question: "What do you think should be the main leadership roles of the head of school?" $(\mathrm{N}=\mathbf{2 4 0})$

\begin{tabular}{|l|l|l|}
\hline Leadership Roles & Frequency & Percentage \\
\hline Supervision of instruction & 72 & 30 \\
Staff developing teachers & 36 & 15 \\
Procuring materials & 40 & 17 \\
Discipline & 38 & 16 \\
Motivating staff & 54 & 22 \\
\hline Totals & $\mathbf{2 4 0}$ & $\mathbf{1 0 0}$ \\
\hline
\end{tabular}

Data from table 4 shows that $30 \%$ of the respondents thought supervision of instruction was the main leadership role of the head of school, $22 \%$ thought motivating staff should be the main role of the head,
$17 \%$ thought he / she should lead in the procurement of resources, $16 \%$ felt he / she should lead in discipline matters and $15 \%$ felt that he should lead through staff developing teachers.

Table-5: Responses to the question: "What type of supervision models does your head use?" $(\mathrm{N}=\mathbf{2 4 0})$

\begin{tabular}{|l|l|l|}
\hline Type of Supervision & Frequency & Percentage \\
\hline Traditional & 4 & 2 \\
Human Relations & 62 & 26 \\
Clinical Supervision & 8 & 3 \\
Scientific & 166 & 69 \\
\hline Total & $\mathbf{2 4 0}$ & $\mathbf{1 0 0}$ \\
\hline
\end{tabular}

The information on table 5 reveals that the majority of respondents felt that their heads used the scientific model of supervision (69\%), $26 \%$ indicated that their heads used the human relations model, while $3 \%$ and $2 \%$ said that their heads used the clinical supervision and traditional models respectively.

Table-6: Responses to the question: "Does your head conduct effective staff development sessions?" (N=240)

\begin{tabular}{|l|l|l|}
\hline Response Category & Frequency & Percentage \\
\hline Yes & 36 & 15 \\
No & 192 & 80 \\
Not Sure & 12 & 5 \\
\hline Total & $\mathbf{2 4 0}$ & $\mathbf{1 0 0}$ \\
\hline
\end{tabular}

The majority of respondents $(80 \%)$ as shown above in table 6 indicated that their heads did not conduct effective staff development sessions. $15 \%$ agreed with the statement and 5\% were not sure.

Table-7: Responses to the question: "What do you think is the leadership style that your head uses?" $(\mathrm{N}=\mathbf{2 4 0})$

\begin{tabular}{|l|l|l|}
\hline Leadership Style & Frequency & Percentage \\
\hline Autocratic & 196 & 82 \\
Laissez-Faire & 4 & 2 \\
Democratic & 30 & 12 \\
Contingency & 10 & 4 \\
\hline Total & $\mathbf{2 4 0}$ & $\mathbf{1 0 0}$ \\
\hline
\end{tabular}


The majority of teachers indicated that their heads used the autocratic leadership style to lead them $(82 \%), 12 \%$ indicated that their heads employed the democratic style, while those who indicated that their heads used the contingency and laissez-faire styles constituted $4 \%$ and $2 \%$ respectively.

Table-8: Responses to the question. "What is the existing climate in your school?" $(\mathrm{N}=\mathbf{2 4 0})$

\begin{tabular}{|l|l|l|}
\hline Climate & Frequency & Percentage \\
\hline Open & 34 & 14 \\
Autonomous & 2 & 1 \\
Controlled & 72 & 30 \\
Closed & 122 & 51 \\
Familiar & 8 & 3 \\
Paternal & 2 & 1 \\
\hline Total & $\mathbf{2 4 0}$ & $\mathbf{1 0 0}$ \\
\hline
\end{tabular}

Table 8 above reveals that most respondents $(51 \%)$ indicated that their schools were characterised by closed climates, $30 \%$ felt they were controlled, $14 \%$ said they were open and $3 \%$ and $1 \%$ said they were autonomous and paternal respectively.

The questionnaire had two open-ended questions which bolstered data from the close-ended questions. The first question wanted to find out from the respondents whether their heads demonstrated on lesson delivery to both old and new teachers. The majority of the respondents indicated that their heads did not have time for demonstration lessons as they were always busy with administrative chores and meetings. The second question sought to find out whether the head made use of senior members of staff to help him / her with other duties like supervision of junior teachers. The majority of respondents indicated that their heads did delegate some of their duties to the deputy heads and heads of departments.

\section{DISCUSSION}

Data from the study reveal that the majority of teachers in the study were experienced professionals who have been in the system for more than ten years. The implications of this finding are that the heads need to use those leadership styles that will not demotivate the experienced teachers. This is corroborated by Harris [16] who state that the head as a leader should work with and through people to achieve the goals of the school and should be able to influence and be influenced by individuals and groups of people so that he/she can go in a desired direction. This means that the head should appreciate he/she is a leader of a team of colleagues and together with the team members they should establish priorities and expected standards for the school and collegially and collectively work to achieve these set standards.

The information from the study also indicates that teachers have their expectations from their heads regarding leading them. Teachers feel that supervision of instruction should supercede all other activities related to leading that the head should do in the school. Teachers also believe that heads as effective leaders should motivate them (teachers) procure materials; staff develops teachers as well as control the behavior of both teachers and pupils. As Plunket and Attner [5] posit, the head's work as a leader is to work with and through people to achieve the goals of the school, that is, provide instructional guidance, motivate teachers, procure materials as well as staff develop teachers.

Data from the study also reveal that most teachers felt that their heads were using the scientific model of supervision. In this kind of model as Ncube [15] observes, the focus of the supervision was the mere efficient use of time in the classroom and routinisation of various activities and the head becomes somewhat of an efficiency monitor, checking to see that teachers were using time effectively. In this model, the school head emphasized measurement and analysis of data to ensure that teachers were productive.

The findings from the study also show that heads did not conduct effective staff development sessions for their teachers. Staff development helps to improve the efficiency and effectiveness of teachers in their delivery of instruction. As Vengesayi [12] states, a major role in staff development is to provide teachers with the capacities and skills to improve instruction. This according to Madziyire [3], can be done by providing teachers with knowledge, competencies and fostering commitment of the staff to the objectives of the school. The head's responsibility in staff development is to ensure that each member of staff becomes and remains a fully competent and responsive teacher of his or her subject and he/she becomes capable of doing his / her job more effectively.

Data also shows that most heads use the autocratic leadership style to lead their teachers. Autocratic leadership is a leadership style characterized by individual control over all decisions and little input from group members. Autocratic leaders typically make choices based on their own ideas and judgements and rarely accept advice from followers. As Bennis [18] postulates, a head who is autocratic creates a climate which is coercive and breeds friction, low morale and a feeling or powerlessness among teachers. Autocratic leadership as Hanson [17] discovered, results in lack of creative solutions to problems, which can ultimately hurt the performance of the group and the school.

Data also reveal that most schools in this study had closed climates or controlled climates. In a closed climate as Madziyire [3] states, the group members obtain little satisfaction from either task-achievement or social needs. The head is ineffective in directing the activities of the teachers and is not interested in looking after the teachers' personal welfare [3]. As Billing [6], observes, in a closed climate teachers do not work 
together, group achievement is minimal, people work on their own as individuals, teachers are not happy at work, the head is highly aloof and impersonal in controlling and directing the activities of the teachers.

\section{CONCLUSIONS}

Given the background of the above findings the researcher makes the following conclusions: -

- The majority of teachers in secondary schools are experienced professionals who have to be properly handled by leaders since, they too, can assist in the running of the schools.

- Teachers have their expectations on areas which heads should prioritise when they are exercising leadership roles in the school. Thus, the need to consult them.

- Most heads still use the scientific model of supervision which emphasizes on control and routinisation of various activities, thereby reducing teachers to mere tools of the trade rather than professional colleagues.

- Most schools did not have effective staff development sessions. Though head's itinerary reflected that they had planned to hold staff development sessions, these were not held.

- Some heads still use the autocratic leadership style and, unfortunately, these are on the majority in schools.

- Most schools have closed climates and teachers are not happy working in these schools.

\section{RECOMMENDATIONS}

In light of the findings of this study, the researcher would like to make some recommendations:

- School heads should involve their senior teachers in decision making about the teaching / learning process so as to tap on the experience they have accumulated over years.

- Heads should devote most of their time, supervising the instructional process as this constitutes the core business of the school.

- Heads should use a combination of supervision models that best suit each individual teacher and situation so as to promote effective teaching and learning.

- Schools should institutionalise staff development sessions that help to develop the professional growth of teachers for better performance of the students.

- School heads should work closely with their teachers to create conducive climates for high pass rates in their schools.

\section{REFERENCES}

1. Dzvimbo CY. A hand book on school administration and management. Harare: College Press.2008.

2. Bowora MG. The supervisory role of TICs. Harare: Zimbabwe Open University.2009.

3. Madziyire CN. Educational leadership and supervision. Harare: Longman. 2010.

4. Nadler I D. Supervision for today's schools. New York: macMillan Publishing Company.2010.

5. Plunket $\mathrm{J}$ and Attner $\mathrm{CP}$. Effective teaching in schools: Theory and Practice. Cheltonham: Stanley Stones.2003.

6. Billing, CL. Running a school. Great Britain: Gilford Limited. 2012.

7. Acheson $\mathrm{AK}$ and Gall MD. Techniques in the clinical supervision of teachers: Perspectives and in-service application. New York: Longman. 1986.

8. Ndlovu TS. Effective teaching in Zimbabwean rural primary schools. Survival Guide for Managers. 2013;30(4):340-54.

9. Knezevich D. Leadership and school achievement. Educational Leadership. 2004;58(3):15-24.

10. Cooper AM and Alvarado JM. Education policy services. International Academy of Education. 2008; 10(5): 56-68.

11. Moyo M. The teachers' views towards supervision. Harare: Longman. 2013.

12. Vengesayi LM. What causes differences in achievement in Zimbabwe. Harare: Zimbabwe Open University.2011.

13. Hoy P and Miskel KL. Supervision of secondary teachers. London: McMillan Publishing Company.2012.

14. Mpofu A. Leadership and achievement in schools. Harare: University of Zimbabwe.2009.

15. Ncube BM. Educational leadership and teachers' performance. Public Personnel Management. 2013; 29(3): 240-256.

16. Harris A. Supervisory behavior in education. London: OUP.2009.

17. Hanson D. Managing schools professionally. London: Harper and Row.2009.

18. Bennis W. Moral leadership: The theory and practice of power, judgment and policy. John Wiley \& Sons; 2006 Jun 12.

19. Blumberg C. Research methods. Boston: Irwin. 2008.

20. Leedy PP. Practical research, Planning and design. New York: MacMillan Press; 2009.

21. Anderson C. Research in education. London: D.P. Publications. 2011.

22. Cresswell JW. Research design: Quantitative, qualitative, and mixed methods. Thousand Oaks, C.A: Sage Publications. 2009.

23. Borg E and Gall R. Educational research and principles. New York: Longman. 2012. 